\title{
Thyroid Cancer in Patients with Hyperthyroidism
}

\author{
Authors \\ K. Pazaitou-Panayiotou ${ }^{1}$, K. Michalakis $^{2}$, R. Paschke ${ }^{3}$ \\ Affiliations \\ Department of Endocrinology-Endocrine Oncology, Theagenion Cancer Hospital, Thessaloniki, Greece \\ ${ }^{2}$ Barts and the London Hospital, Queen Mary University, London, UK \\ ${ }^{3}$ Department for Endocrinology and Nephrology Leipzig University, Leipzig, Germany
}

Key words

- Graves' disease

- toxic multinodular goiter

hot nodules

- hyperthyroidism

- thyroid cancer received 18.10.2011

accepted 13.12.2011

\section{Bibliography}

DOI http://dx.doi.org/

10.1055/s-0031-1299741

Published online:

February 14, 2012

Horm Metab Res 2012;

44: 255-262

(c) Georg Thieme Verlag KG

Stuttgart · New York

ISSN 0018-5043

Correspondence

K. Pazaitou-Panayiotou

2, Al Simeonidi St.

54007 Thessaloniki

Greece

Tel.: $+30 / 2310 / 898810$

Fax: +30/2310/898 809

kpazaitou@in.gr

\section{Abstract}

$\nabla$

Thyroid cancer can be associated with thyrotoxicosis caused by Graves' disease, toxic multinodular goiter, or autonomously functioning thyroid adenoma. The objective of this study was to summarize current evidence regarding the association of thyroid cancer and hyperthyroidism, particularly with respect to the type of hyperthyroidism found in some patients, and whether this affects the outcome of the patient. A PubMed search was performed up to August 2011. Articles were identified using combinations of the following keywords/phrases: thyroid cancer, papillary thyroid cancer, follicular thyroid cancer, medullary thyroid cancer, ana-

\section{Introduction}

$\nabla$

In 1937 Means [1] suggested that hyperthyroidism might be protective against thyroid cancer and this initially gained some support, but was soon abandoned due to findings in the following decades. Supportive of that are reports performed in the 1950's that indicated a low incidence of thyroid cancer in patients with Graves' disease in the range of $0.15-0.5 \%[2,3]$ or even a slightly higher incidence of $2.5 \%$ [4]. All the above data were based on patients treated with subtotal thyroidectomy. However, later studies by Shapiro et al. on patients with Graves' disease demonstrated an unsuspected thyroid cancer in $8.7 \%$ of them [5]. This increase was probably observed due to the fact that the patients were treated with total thyroidectomy; a more intense histological examination of the surgical specimen further increased the chances of diagnosing thyroid cancer [6,7].

To further complicate the matter, discrepancies appear not only in reports on the incidence but also on the aggressiveness of thyroid cancer associated with hyperthyroidism. For instance, while plastic thyroid cancer, hyperthyroidism, Graves' disease, autonomous adenoma, toxic thyroid nodule, and toxic multinodular goiter. Original research papers, case reports, and review articles were included. We concluded that the incidence, as well as the prognosis of thyroid cancer associated with hyperthyroidism is a matter of debate. It seems that Graves' disease is associated with larger, multifocal, and potentially more aggressive thyroid cancer than single hot nodules or multinodular toxic goiter. Patients with Graves' and thyroid nodules are at higher risk to develop thyroid cancer compared to patients with diffuse goiter. Every suspicious nodule associated with hyperthyroidism should be evaluated carefully.

some reports describe the cancer as very aggressive $[8,9]$, often invasive, and metastatic to regional lymph nodes, even when the primary tumor is small [10] and possibly fatal [11,12]; in other series the clinical course was not different from euthyroid patients [13]. Up to date the reasons for these discrepancies have not been solved and the incidence and aggressiveness of thyroid cancer remain controversial.

This review attempts to shed some light on the reasons behind these discrepancies in order to gain a better understanding in the association and the evolution of thyroid cancer in patients with hyperthyroidism, particularly with respect to the type of hyperthyroidism found in some patients and whether this co-existence affected the outcome of the patients.

\section{Methods \\ $\nabla$}

This is a literature review based on articles found in PubMed up to August 2011. An electronic search of Pubmed/Medline database using the MeSH (Medical Subjected Headings) was performed, 
Table 1 Incidence of thyroid carcinoma in hyperthyroid patients (Graves', autonomous adenoma, toxic multinodular goiter).

\begin{tabular}{|lccc|} 
Author & $\begin{array}{c}\text { Hyperthyroid } \\
\text { patients } \mathbf{( n )}\end{array}$ & $\begin{array}{c}\text { Thyroid } \\
\text { cancer } \mathbf{n}\end{array}$ & $\begin{array}{c}\text { Thyroid } \\
\text { cancer \% }\end{array}$ \\
\hline Taneri [15] & 120 & 10 & 8.3 \\
\hline Cappelli C [8] & 691 & 32 & 4.7 \\
\hline Terzioglou [19] & 138 & 8 & 5.8 \\
\hline Gabriele [22] & 425 & 7 & 1.6 \\
\hline Cakir [18] & 375 & 26 & 6.9 \\
\hline Vaiana [21] & 512 & 24 & 4.7 \\
\hline Linos [20] & 400 & 27 & 7.0 \\
\hline Pacini [14] & 179 & 11 & 6.1 \\
\hline Lin [24] & 45 & 6 & 13.3 \\
\hline Lian [94] & 394 & 12 & 3.0 \\
\hline Senyurek Giles [17] & 817 & 53 & 6.5 \\
\hline Calò [26] & 71 & 15 & 21.1 \\
\hline Sahin [16] & 333 & 13 & 3.9 \\
\hline Zanella [25] & 202 & 12 & 5.9
\end{tabular}

Table 2 Percentage incidence of microcarcinomas in patients with both thyroid cancer and hyperthyroidism.

\begin{tabular}{|c|c|c|c|c|}
\hline Author & $\begin{array}{l}\text { Thyroid } \\
\text { Cancer } \\
\text { patients (n) }\end{array}$ & $\begin{array}{l}\text { Type of hyper- } \\
\text { thyroidism }\end{array}$ & $\begin{array}{l}\text { Tumor } \\
\text { size } n\end{array}$ & $\begin{array}{l}\leq 10 \mathrm{~mm} \\
\%\end{array}$ \\
\hline Farbota [34] & 6 & Graves' disease & 3 & 50.0 \\
\hline Belfiore [31] & 22 & $\begin{array}{l}\text { Graves' disease, } \\
\text { hot nodule }\end{array}$ & 11 & 50.0 \\
\hline Ahuja [72] & 20 & All types & 7 & 35.0 \\
\hline Vini [102] & 23 & All types & 12 & 51.2 \\
\hline Ozaki [10] & 19 & Graves' disease & 9 & 47.4 \\
\hline Cakir [18] & 26 & All types & 9 & 34.6 \\
\hline Cerci [92] & 11 & $\begin{array}{l}\text { Multinodular } \\
\text { goiter }\end{array}$ & 8 & 72.7 \\
\hline Taneri [15] & 10 & All types & 7 & 70.0 \\
\hline Chao [49] & 61 & Graves' disease & 49 & 80.3 \\
\hline $\begin{array}{l}\text { Pazaitou- } \\
\text { Panayiotou [11] }\end{array}$ & 60 & All types & 39 & 65.0 \\
\hline Pellegriti [32] & 36 & Graves' disease & 15 & 41.7 \\
\hline Lian [94] & 12 & All types & 7 & 58.3 \\
\hline Omur [96] & 76 & All types & 50 & 65.7 \\
\hline Gerenova [37] & 8 & Graves' & 7 & 88.0 \\
\hline Erbil [38] & 18 & Graves' & 15 & 83.3 \\
\hline Hales [13] & 16 & Graves' & 14 & 87.0 \\
\hline
\end{tabular}

using combinations of the following keywords/phrases: thyroid cancer, papillary thyroid cancer, follicular thyroid cancer, medullary thyroid cancer, anaplastic thyroid cancer, hyperthyroidism, Graves' disease, autonomous adenoma, toxic thyroid nodule, and toxic multinodular goiter. Original research papers, case reports, and review articles were included in the present review.

\section{Findings}

$\nabla$

\section{Thyroid cancer in patients with hyperthyroidism}

The prevalence of thyroid carcinomas found during surgery in hyperthyroid patients, is reported to vary widely, ranging up to $21.1 \%[8,14-26]$ ( 0 Table 1 ). This is probably due to multiple factors, including the cause of hyperthyroidism, the different criteria for choosing surgery as the treatment modality of hyper- thyroidism, the extent of thyroidectomy (lobectomy or total thyroidectomy), but most likely due to the extent of histological examination of the removed thyroid tissue and possibly also the geographical variation in incidence of thyroid cancer in general $[27,28]$. All histological types of thyroid cancers can be associated with all types of hyperthyroidism, although the most frequently reported type is papillary thyroid carcinoma, followed by follicular thyroid carcinoma, and rarely by anaplastic carcinoma and medullary thyroid carcinoma $[11,12,29,30]$, in keeping with the lower incidence of these cancers in general.

It has been reported that thyroid cancer is diagnosed more frequently in patients with Graves' disease than in patients with uninodular toxic goiter or toxic multinodular goiter (TMG) [8] whereas other studies presented the same results for Graves', but slightly higher carcinoma prevalence within hot nodules and TMG $[17,18]$. In Graves' patients, carcinomas are found to be larger, more often multifocal, locally invasive and more often metastatic to distant sites than in patients with hot thyroid nodules [31].

Most carcinomas are small in size $[10,13,32]$ and the majority are microcarcinomas ( $\boldsymbol{0}$ Table $\mathbf{2}$ ). In many cases thyroid cancer is not known preoperatively, but is found incidentally during postoperative histologic examination of the thyroid [33]. We previously reported a study of 60 hyperthyroid patients diagnosed with thyroid cancer [11]. Among those patients, only 12 were operated for suspicion of thyroid cancer preoperatively, whereas in the remaining 48 , in whom the indication for thyroidectomy was treatment for thyrotoxicosis, thyroid cancer was incidentally found after surgery. No significant differences were found in clinical characteristics at presentation between coincidentally discovered thyroid cancers and preoperatively known clinical cancers. The time of diagnosis of hyperthyroidism to thyroidectomy was not different. However, Miccoli et al. reported that, the diagnosis of incidental thyroid carcinoma in patients who were operated on for a benign disease was more frequent in euthyroid patients than in patients with hyperthyroidism [23].

\section{Thyroid cancer in patients with Graves' disease Prevalence}

The prevalence of thyroid carcinoma in Graves' hyperthyroidism has been examined over many years but the issue still remains controversial. There are significant differences in the reported incidence of thyroid cancer in patients operated for Graves' disease, ranging between 0.5 and $15.0 \%,[2-5,8,10,14,16-21,23$, 31,34-39], ( 0 Table 3). Some studies suggest an association between Graves' disease and thyroid cancer $[8,14,18,34,40]$ as the annual incidence of clinical thyroid cancer in patients with Graves' disease was reported as 175/100000 [32], well above the incidence of 0.5-8.0/100 000 reported for the general euthyroid population [41].

\section{Aggressiveness}

It has been reported that, thyroid carcinoma concurrent to Graves' disease is usually aggressive [40] and metastatic to regional lymph nodes [8], even when the primary tumor is small [10] and that it has a worse clinical outcome compared to euthyroid patients with differentiated thyroid cancer $[8,31,32,42,43]$. Lymph nodes involvement was found in up to $61.5 \%$ of the patients $[8,31]$ and the incidence of locally advanced cancers was significantly higher in older patients [44].

However, some studies report discordant results or do not highlight the aggressive characteristics of thyroid carcinomas in 
Table 3 Prevalence of thyroid carcinoma in Graves' disease.

\begin{tabular}{|lrrr|}
\hline & Graves' disease & \multicolumn{2}{c}{ Thyroid cancer } \\
& $\mathbf{n}$ & $\mathbf{n}$ & $\%$ \\
\hline Beahrs [3] & 3022 & 14 & 0.5 \\
\hline Sokal [2] & 13868 & 21 & 0.15 \\
\hline Olen [4] & 2114 & 53 & 2.5 \\
\hline Pacini [14] & 86 & 6 & 6.9 \\
\hline Shapiro [5] & 172 & 15 & 8.7 \\
\hline Farbota [34] & 117 & 6 & 5.1 \\
\hline Belfiore [31] & 132 & 13 & 9.8 \\
\hline Sahin M [16] & 144 & 5 & 3.5 \\
\hline Terzioglou [19] & 33 & 4 & 6.0 \\
\hline Vaiana [21] & 108 & 7 & 6.4 \\
\hline Cappelli [8] & 145 & 9 & 6.5 \\
\hline Ozaki [10] & 743 & 19 & 2.6 \\
\hline Cakir [18] & 67 & 4 & 6.0 \\
\hline Pellegriti [32] & 450 & 21 & 4.7 \\
\hline Gerenova [37] & 103 & 8 & 7.8 \\
\hline Kraimps [39] & 557 & 21 & 15.0 \\
\hline Erbil [38] & 150 & 18 & 12.0 \\
\hline Lee [35] & 779 & 58 & 7.4 \\
\hline Senyurek Giles [17] & 342 & 13 & 3.8 \\
\hline
\end{tabular}

Graves' disease [13,37,45-47]. Hales et al. compared 16 patients with Graves' disease with concomitant thyroid cancer with a group of euthyroid patients with thyroid cancer who underwent surgery during the same time period and were matched for sex and age to the patients with Graves' disease [13]. The authors did not find increased aggressiveness of thyroid cancer in patients with Graves' disease when compared to euthyroid subjects. In this study the mean tumor diameter in the Graves' group was $1.0 \mathrm{~cm}$ and in the control group $2.5 \mathrm{~cm}$ and this is an obvious disadvantage of the study. The outcome may suggest that small carcinomas in Graves' patients have the same prognosis as larger carcinomas in euthyroid patients. Yano et al. compared the features of 154 cases of papillary thyroid cancers diagnosed in patients with Graves' disease to a euthyroid group with thyroid cancer [46] and did not find significant differences in multifocality, lymph node metastases, or distant metastases between the Graves' disease and the euthyroid group. Edmonds et al., in their study with 502 patients with thyroid cancer, reported similar mortality rates when comparing patients with Graves' disease and with multinodular goiter to that of euthyroid patients matched for age [45].

All the above mentioned studies are retrospective and explore different clinical or histological parameters and therefore are not totally comparable. Prospective studies with a large number of patients could give clear answer about the aggressiveness of thyroid cancer in GD.

\section{Microcarcinomas - Clinically important cancers}

Most carcinomas associated with Graves disease are small $[10,13,32]$ and are found incidentally during postoperative histological examination of the thyroid $[33,48]$. Incidental cancers of $\leq 10 \mathrm{~mm}$ were found up to $88.0 \%$ of all cancers detected in Graves' disease $[10,13,32,34,37,38,49]$. The clinical significance of these microcarcinomas is uncertain. In a recent report, patients with microcarcinomas and concomitant Graves' disease were compared with euthyroid patients with cancers of equal size and were found to have an excellent prognosis and longer disease-free survival [42].
Pellegriti et al. evaluated the frequency and the evolution of incidentally found vs. clinically important thyroid carcinomas in 450 Graves' patients who underwent thyroidectomy, in 2 different studies in the periods 1982-1987 and 1988-1994 [32]. The overall frequency of incidentally found carcinomas in Graves' patients undergoing surgery was 3.33\% (15/450) and that of clinically important thyroid carcinomas was $4.7 \%$ (21/450). All patients with microcarcinoma were disease-free except for one case that developed a local recurrence. On the contrary, patients with clinically important disease presented lymph nodes metastases, distant metastases and deaths (odd ratios $=3.14$ as compared with euthyroid patients). In the study of Lee et al. clinically overt thyroid carcinomas were diagnosed in 3.3\% and incidental carcinoma in $4.2 \%$ of patients with Graves' disease [35]. In this study comparison of clinical findings of incidental and clinical carcinoma patients revealed no difference between the 2 groups in terms of duration of thyrotoxic symptoms, serum levels of thyroid hormones before the administration of antithyroid drugs, and postoperative serum concentration of thyroglobulin. Local recurrence was identified in 4 patients (6.9\%), all of whom belonged to the clinical carcinoma group. This finding supports the conclusion that thyroid microcarcinomas in Grave's disease seldom cause metastasis.

\section{Nodular Graves' disease}

It appears that thyroid nodules in Graves' goiters have a greater risk of malignancy. Thyroid carcinoma occurs in $3-10 \%$ of palpable nodules in general, whereas the numbers for incidentally found nonpalpable nodules vary very widely, according to different studies, mostly due to differences in iodine availability [5052]. Kraimps et al. in their multicentric study with 557 patients who underwent thyroidectomy for Graves' disease found that the incidence of thyroid carcinoma associated with Graves' disease was 3.8\% [39]. This incidence was higher and - actually $15 \%$, if patients with a nodule were considered. Pacini et al. reported that when a thyroid nodule was present in a toxic diffuse goiter the possibility to find a carcinoma reached $22.2 \%$ of the cases, while only $2.9 \%$ with diffuse toxic goiter, without a nodule, had thyroid cancer [14]. Due to this finding the authors conclude that in patients with Graves' disease any nodule must be screened carefully to rule out malignancy. Belfiore et al. reviewed previously published data on the incidence of thyroid cancer in Graves' patients with or without thyroid nodules and found that the incidence of thyroid cancer in patients with nodules was up to $45.8 \%$ of the cases in contrast to those without nodules in whom thyroid cancer did not exceed 9.8\% [53]. Thyroid scintigraphy is an important test in the evaluation of patients with Graves' disease and nodules, and the prevalence of thyroid cancer in a cold nodule provides justification for further diagnostic evaluation [54]. In the recently published medical guidelines for clinical practice for the diagnosis and management of thyroid nodules it is recommended that nodules in Graves' disease should be managed in the same way as any other thyroid nodule including follow-up and consideration of a second FNAB to reduce the number of false negative results [55]. Fine-needle aspiration cytology from nodules, which are found in patients with Graves' disease, can cause diagnostic difficulties because the cytomorphologic changes in this disease as a consequence of antithyroid drug treatment may mimic features of papillary thyroid carcinoma. Furthermore, atypia produced by the administration of radioactive iodine (RAI) may be severe, leading to an erroneous diagnosis of malignancy [56]. Provision 
of the appropriate clinical history of Graves' disease treated with RAI may prevent this pitfall. In a recent study nuclear elongation, pale powdery chromatin, intranuclear grooves, and small eccentric nucleoli were found to be significant for the diagnosis of PTC arising in GD [57].

\section{Diagnosis of thyroid cancer according to Graves' initial treatment}

Thyroid cancer associated with Graves' disease is found more commonly in surgically treated patients than in patients after radioactive iodine therapy. Ozaki et al. reported a $0.17 \%$ thyroid cancer incidence in Graves' patients treated with radioactive iodine vs. 2.5\% in Graves' patients treated with surgery [58]. In a study by Behar et al., 303 patients received RAI therapy for Graves' disease and only one ( $0.3 \%)$ subsequently developed thyroid carcinoma [40]. Of course, one could claim that patients undergoing surgery have a higher chance of a cancer being recognized, when compared to radioiodine treated patients.

\section{Pathogenesis}

The possible reasons that could explain the increased frequency and aggressiveness of clinical thyroid cancer reported by some studies for patients with Graves' disease are not clear. Thyroid stimulating hormone (TSH), by binding to the thyroid-stimulating hormone receptor (TSHR), and probably multiple other factors, affect the evolution of thyroid cancer. Neoplastic cells of differentiated thyroid cancer, like normal thyroid cells, express functional receptors for TSH.

Graves' disease is characterized by a marked decrease in TSH [59]. In Graves', antibodies (TSAbs) are produced that have strong agonistic activity to the TSHR, and this results in antibody-mediated stimulation of the receptor. Stimulation of TSHR by antibodies leads to secretion of thyroid hormone and hyperthyroidism independently of the hypothalamic-pituitary-thyroid axis. Moreover, TSAbs might play a role in stimulating thyroid cancer growth, invasiveness $[9,60]$ and angiogenesis by upregulating vascular endothelial growth factor, placenta growth factor, and their receptors. TSAbs use the same signaling pathways that are used by TSH for cell activation and growth [61]. Taking into consideration that chronic TSH stimulation affects the prognosis of thyroid cancer it could be postulated that the TSH mimicking effect of TSAbs could explain the increased aggressiveness of thyroid cancer in Graves' patients. Apart from that, different growth factors that probably are produced by the over stimulated, by TSAbs, and hypervascularized thyroid [31] could also affect the growth and metastases of thyroid cancer in Graves' patients.

\section{Extent of surgery}

The extent of surgery for thyroid carcinoma concomitant with Graves's disease has rarely been discussed. As clinically important thyroid cancers associated with Graves's disease seems to behave more aggressively, with a tendency to lymph node metastases, total or near-total thyroidectomy plus central neck dissection are recommended [32]. In these cases surgical treatment for thyroid carcinoma is the goal and this surpasses the surgical treatment for hyperthyroidism.

Carcinomas smaller than $10 \mathrm{~mm}$ concomitant with Graves disease could be treated by subtotal thyroidectomy with excellent outcomes [62]. 2 guidelines for the management of thyroid cancer have been published by European and American thyroid associations. Both agree that if papillary thyroid microcarci- noma (PTM) is diagnosed preoperatively, total or near-total thyroidectomy is the treatment of choice, because it eliminates multifocal disease and decreases the recurrence rate. If PTM is found after total or near-total thyroidectomy for multinodular goiter or Graves' disease both guidelines state that no further treatment is indicated when the PTM is unifocal, well-differentiated, without lymph node metastases or extrathyroidal invasion $[63,64]$. Recently, the revised guideline of the American thyroid association suggests that lobectomy alone is a sufficient treatment for small ( $<1 \mathrm{~cm}$ ), low-risk, unifocal, intrathyroidal papillary carcinomas in the absence of head and neck irradiation or cervical lymph nodes metastases [65]. Obviously this recommendation would not be applicable for patients with Graves' hyperthyroidism, as lobectomy is no sufficient treatment for relapsing Graves' disease. Evidence-based criteria support total thyroidectomy as the surgical technique of choice when surgery is considered for definitive management for Graves' disease [66].

Thyroid cancer in patients with autonomous adenoma Most autonomously functioning thyroid nodules (AFTN) are benign follicular neoplasms but rarely patients with toxic adenoma may harbor thyroid cancer in the autonomously functioning nodule. These mainly involve papillary and less often follicular or Hurthle histological types. The published data regarding the association of thyroid cancer and hot nodules are few, and are mostly limited to case reports or series with a small numbers of patients [67-71]. The reported probability of a hot nodule being associated with malignancy (i.e., a thyroid carcinoma in or outside the hot nodule) ranges between $1-10.3 \%$ $[8,18,49,72-77]$ ( Table 4). An exception to that is one small series where the incidence of cancer in hot nodules was $44 \%$ [64]. Schröder and Marthaler reviewed 30 reports of warm or hot thyroid carcinomas published between 1989 and 1996 and found that only in 10 of these 30 cases the carcinoma was clearly described as located inside the hot nodule [78]. Similar findings were reported in many other studies $[8,11,17,22,73,79]$. However, hot nodules in children seem to carry a higher risk of malignancy of up to $29 \%$ of thyroid carcinomas within the hot nodules [80,81].

The true incidence of thyroid cancer in patients with autonomous adenomas may be underestimated because occasionally large doses of radioiodine are used to treat such cases if they do not undergo surgery, which may be sufficient not only to cure the thyrotoxicosis but also the cancer. However, in a recent report by Als et al. in 5 of 19 patients, one or more courses of ${ }^{131}$ I were preoperatively administered to the autonomously func-

Table 4 Incidence of thyroid carcinoma in patients with autonomous adenoma (inside or outside the hot nodule).

\begin{tabular}{|l|ccc|}
\hline Author & $\begin{array}{l}\text { Toxic } \\
\text { adenoma } \mathbf{n}\end{array}$ & $\begin{array}{l}\text { Thyroid } \\
\text { cancer } \mathbf{~}\end{array}$ & $\begin{array}{l}\text { Thyroid } \\
\text { cancer \% }\end{array}$ \\
\hline Senyurek Giles [17] & 176 & 21 & 12.0 \\
\hline Vaiana [21] & 153 & 8 & 5.2 \\
\hline Cappelli [8] & 207 & 10 & 4.8 \\
\hline Gabriele [22] & 120 & 3 & 2.5 \\
\hline Cakir [18] & 63 & 4 & 6.3 \\
\hline Foppiani [36] & 16 & 2 & 2.5 \\
\hline Harach [76] & 73 & 6 & 8.2 \\
\hline Smith [77] & 30 & 2 & 6.6 \\
\hline Hamburger [74] & 29 & 3 & 10.3 \\
\hline Sahin [6] & 77 & 6 & 7.8 \\
\hline
\end{tabular}


Table 5 All patients reported up to date with a differentiated hot thyroid carcinoma.

\begin{tabular}{|c|c|c|c|c|c|c|}
\hline $\begin{array}{l}\text { Activating } \\
\text { TSHR } \\
\text { mutations }\end{array}$ & $\begin{array}{l}\text { Cell surface } \\
\text { expression } \\
\text { percent of wt }\end{array}$ & $\begin{array}{l}\text { cAMP accumulation } \\
\text { (according to SSFA } \\
\text { of GPHRs) Basal } \\
\text { (wt }=100 \% \text { ) }\end{array}$ & $\begin{array}{l}\text { IP accumulation } \\
\text { (according to SSFA } \\
\text { of GPHRs) Basal } \\
\text { (wt=100\%) }\end{array}$ & $\begin{array}{l}\text { RAS, RAF, p53, } \\
\text { and MAPK } \\
\text { activation }\end{array}$ & Histopathology of the tumor & Age/Sex \\
\hline T632I & $\begin{array}{l}40 \\
50\end{array}$ & $\begin{array}{l}420 \\
330\end{array}$ & $\begin{array}{l}\text { n.d. } \\
\text { n.d. }\end{array}$ & Not studied & Follicular carcinoma & $50 / \mathrm{M}$ \\
\hline $\mathrm{D} 633 \mathrm{H}$ & 84 & 620 & 221 & No mutations & Insular thyroid carcinoma & $60 / \mathrm{F}$ \\
\hline I486F & $\begin{array}{l}17 \\
20 \\
35\end{array}$ & $\begin{array}{l}550 \\
400 \\
820\end{array}$ & $\begin{array}{l}327 \\
\text { n.d. } \\
97\end{array}$ & Not studied & $\begin{array}{l}\text { Follicular carci-noma (capsular } \\
\text { invasion) }\end{array}$ & $49 / \mathrm{F}$ \\
\hline M453T & $\begin{array}{l}\text { n.d. } \\
66\end{array}$ & $\begin{array}{l}700 \\
570\end{array}$ & $\begin{array}{l}\text { n.d. } \\
103\end{array}$ & Not studied & Papillary carcinoma & $11 / \mathrm{F}$ \\
\hline D633Y & $60^{*}$ & 405 & 127 & PAX8-PPARY & Follicular carcinoma & $59 / M$ \\
\hline F631I & n.d. & n.d. & n.d. & & & \\
\hline L512R & 56 & 325 & 100 & Not studied & Papillary carcinoma & $52 / \mathrm{F}$ \\
\hline
\end{tabular}

The cell surface expression determined by TSH binding

The expression levels of the respective constructs were evaluated by FACS analysis. LRA has only been reported for TSHR mutation M453T (LRA: 5.2)

TSHR: thyroid stimulating hormone receptor; GPHR: glycoprotein hormone receptor; wt: wild type; LRA: linear regression analyses; FACS: Fluorescence-activated cell sorting

Table 6 Incidence of thyroid carcinoma in patients with toxic multinodular goiter $\mathrm{n}=$ number of patients.

\begin{tabular}{|llll|}
\hline Author & $\begin{array}{l}\text { Toxic multinodular } \\
\text { goiter } \mathbf{n}\end{array}$ & $\begin{array}{l}\text { Thyroid } \\
\text { cancer } \mathbf{~}\end{array}$ & $\begin{array}{l}\text { Thyroid } \\
\text { cancer \% }\end{array}$ \\
\hline Cerci [99] & 124 & 11 & 8.8 \\
\hline Senyurek Giles [17] & 299 & 19 & 6.4 \\
\hline Vaiana [21] & 251 & 10 & 3.9 \\
\hline Cappelli [8] & 339 & 13 & 3.9 \\
\hline Gabriele [22] & 241 & 4 & 1.6 \\
\hline Cakir [18] & 245 & 18 & 7.3 \\
\hline Sahin [16] & 112 & 2 & 1.8 \\
\hline
\end{tabular}

Table 7 Incidence of all types of hyperthyroidism in patients with thyroid cancer.

\begin{tabular}{|lccc|}
\hline Author & $\begin{array}{l}\text { Thyroid } \\
\text { carcinoma }\end{array}$ & \multicolumn{2}{c|}{ Hyperthyroidism (all types) } \\
& & & \\
& & $\mathbf{n}$ & $\%$ \\
\hline Kilpatrick [97] & 100 & 7 & 7.0 \\
\hline Hancock [98] & 120 & 10 & 8.3 \\
\hline Mazzaferri [99] & 576 & 19 & 3.3 \\
\hline Hall [100] & 79 & 3 & 3.8 \\
\hline Wahl [101] & 554 & 23 & 4.2 \\
\hline Edmonds [45] & 502 & 22 & 4.2 \\
\hline Ahuja [72] & 251 & 22 & 8.8 \\
\hline Vini [102] & 986 & 23 & 2.3 \\
\hline Bolko [103] & 217 & 20 & 9.1 \\
\hline Pazaitou-Panayiotou [11] & 720 & 60 & 8.3 \\
\hline Gulcelik [104] & 422 & 12 & 2.8 \\
\hline Lian [94] & 245 & 12 & 4.9 \\
\hline Omur [96] & 1800 & 76 & 4.2 \\
\hline Calò [26] & 110 & 15 & 13.6 \\
\hline
\end{tabular}

tioning thyroid nodule that initially had been mistaken for benign and after thyroidectomy proved to be thyroid cancer [82]. The same is reported by other authors [68].

There are reports of malignant hot nodules, in which activating mutations of the thyrotropin receptor (TSHR) gene were identified [83-90]. Among these the I486F, T620I, F631I, D633Y, T632A, and T632I activating TSHR gene mutations were identified in 5 follicular carcinomas, the D633H mutation in one insu- lar, the M453T and L512R mutations in 2 papillary (one per one) and the L677V in one Hürthle cell carcinoma. However, functional reanalysis of these reported TSH receptor mutations revealed that only the hot thyroid carcinomas with the TSHR mutations M453T, I486F, L512R, F631I, T632A, T632I, D633H and D633Y were associated with constitutively activating TSHR mutations [91], (๑ Table 5).

\section{Thyroid cancer in patients with toxic multinodular goiter}

Whereas carcinomas, largely of the papillary type, occur in nontoxic nodular goiters with a reported frequency of $4-17 \%$ of cases, the reported incidence of thyroid cancer in patients with hyperfunctioning multinodular goiter ranges between 1.8-8.8\% [8,16-18,21,22,92-95], ( 0 Table 6). However, the data available in the literature regarding the incidence and the evolution of the disease are controversial. Cerci et al. found no significant difference for the incidence of thyroid cancer between toxic and nontoxic multinodular goiter [92]. In another study, lymph node involvement was found in $23 \%$ of the cases with toxic multinodular goiter and cancer [17]. In a third one, 43 toxic multinodular goiters were associated with differentiated thyroid cancer. No lymph node metastases were detected in this latter study although distant metastases were found in 3 cases [96]. The variable findings in these 3 studies are difficult to explain and to understand.

\section{Incidence of hyperthyroidism in cancer patients}

Most of the reports examined the incidence of thyroid cancer in patients with hyperthyroidism and there are only few reports looking for the incidence of hyperthyroidism in patients operated on for thyroid cancer which is reported to be up to $14 \%$ $[11,17,26,45,72,94,96-104]$, ( $\odot$ Table 7 ). It would be very interesting to compare the evolution of thyroid cancer in both euthyroid and hyperthyroid patients in these studies in order to really understand if thyroid cancer progresses in a different way, depending on the metabolic condition of the thyroid gland.

\section{Conclusions}

Hyperthyroidism is a benign disease. Some patients with Graves' disease are treated with antithyroid drugs for many years. This often leads to underestimation of the risk of thyroid cancer and 
to a delay in performing thyroidectomy, which should be the choice of treatment in patients with Graves' disease and suspicious nodules [40]. Evaluation of the malignancy risk of a nodule in patients with Graves' disease appears to be crucial. Creation of rodent models of thyroid cancers and hyperthyroidism could elucidate molecular genetic changes underlying cancer development and progression [105].

Patients with a toxic nodule or toxic multinodular goiter usually undergo thyroid ablation soon after the diagnosis of hyperthyroidism and therefore rarely receive prolonged antithyroid treatment. These patients are at low risk for developing thyroid carcinoma in the toxic nodules based on the data reported above. It is important to perform thyroid and neck US and US-guided FNAC prior to radioiodine therapy or thyroidectomy [16], in order to detect thyroid cancer. US-FNAC should be focused on lesions, which appear suspicious by US features as stated by the Consensus of Society of Radiologists in Ultrasound [55, 106], and not on larger or clinical dominant nodules. In cases of nodules that show suspicious features and when it is not possible to exclude the possibility of malignancy by fine needle aspiration cytology, the preferred choice of treatment should be surgery. The detection of the rare truly hot thyroid carcinomas remains a clinical challenge.

Unfortunately all the reported series in the present review are retrospective. Therefore, it is impossible to know the selection criteria, which have led to choose surgery: treatment of hyperthyroidism or because a nodule was suspicious? Prospective multicenter studies based on such selection could answer if the incidence and progression of thyroid cancer is different or not.

\section{References}

1 Means JH. The thyroid and its diseases. Philadelphia: JB Lippincott Co, 1937; 482

2 Sokal JE. Incidence of malignancy in toxic and non-toxic nodular goiter. JAMA 1954; 154: 1321-1325

3 Beahrs $\mathrm{OH}$, Pemberton J, Black BM. Nodular goiter and malignant lesion of the thyroid gland. J Clin Endocrinol 1951; 11: 1157-1165

4 Olen E, Klinck GH. Hyperthyroidism and thyroid cancer. Arch Pathol 1966; 81: 531-535

5 Shapiro SJ, Friedmam NB, Perzik SL, Catz B. Incidence of thyroid carcinoma in Graves' disease. Cancer 1970; 26: 1261-1270

6 Davies L, Welch $H G$. Increasing incidence of thyroid cancer in the United States, 1973-2002. JAMA 2006; 295: 2164-2167

7 Enewold L, Zhu K, Ron E, Marrogi AJ, Stojadinovic A, Peoples GE, Devesa SS. Rising thyroid cancer incidence in the United States by demographic and tumor characteristics, 1980-2005. Cancer Epidemiol Biomarkers Prev 2009; 18: 784-791

8 Cappelli C, Braga M, Martino ED, Castellano M, Gandossi E, Agosti B, Cumetti D, Pirola I, Mattanza C, Cherubini L, Rosei EA. Outcome of patients surgically treated for various forms of hyperthyroidism with differentiated thyroid cancer: Experience at an Endocrine Center in Italy. Surg Today 2006; 36: 125-130

9 Mazzaferri EL. Thyroid cancer and Graves's disease. J Clin Endocrinol Metab 1990; 70: 826-829

10 Ozaki O, Ito K, Kobayashi K, Toshima K, Iwasaki H, Yashiro T. Thyroid carcinoma in Graves' disease. World J Surg 1990; 14: 437-441

11 Pazaitou-Panayiotou K, Perros P, Boudina M, Drimonitis A, Siardos G, Patakiouta F, Vainas I. Mortality from thyroid cancer in patients with hyperthyroidism: the Theagenion Cancer Hospital experience. Eur Journal Endocrinol 2008; 159: 799-803

12 Hayes FJ, Sheaham K, Heffernan A, McKenna TJ. Aggressive thyroid cancer associated with toxic nodular goitre. Eur J Endocrinol 1996; 134: $366-370$

13 Hales IB, McElduff Crummer P, Clifton-Bligh P, Delbridge L, Hoschl R, Poole A, Reeve TS, Wilmshurst E, Wiseman J. Does Graves' disease or thyrotoxicosis affect the prognosis of thyroid cancer. J Clin Endocrinol Metab 1992; 75: 886-889

14 Pacini F, DiCoscio GC, Anelli S, Macchia E, Concetti R, Miccoli P, Arganini $M$, Pinchera A. Thyroid carcinoma in thyrotoxicosis patients treated by surgery. J Endocrinol Invest 1988; 11: 107-112
15 Taneri F, Kurukahvecioglu O, Ege B, Yilmaz U, Tekin EH, Cifter C, Onuk $E$. Clinical presentation and treatment of hyperthyroidism associated with thyroid cancer. Endocr Regul 2005; 39: 91-96

16 Sahin M, Guvener ND, Ozer F, Sengul A, Ertugrul D, Tutuncu NB. Thyroid cancer in hyperthyroidism: incidence rates and value of ultrasound-guided fine-needle aspiration biopsy in this patient group. J Endocrinol Invest 2005; 28: 815-818

17 Senyurek Giles Y, Tunka F, Boztepe H, Kapran Y, Terzioglu T, Tezelman $S$. The risk factors for malignancy in surgically treated patients for Graves' disease, toxic multinodular goiter, and toxic adenoma. Surgery 2008; 144: 1028-1037

18 Cakir M, Arici C, Alakus H, Altunbas H, Balci MK, Karayalcin U. Incidental thyroid carcinoma in thyrotoxic patients treated by surgery. Horm Res 2007; 67: 96-99

19 Terzioglou T, Tezelman S, Onaran Y, Tanakol R. Concurrent hyperthyroidism and thyroid carcinoma. Br J Surg 1993; 80: 1301-1302

20 Linos DA, Karakitsos D, Papademetriou J. Should the primary treatment of hyperthyroidism be surgical? Eur J Surg 1997; 163: 651-657

21 Vaiana R, Cappelli C, Perini P, Pinelli D, Camoni G, Farfaglia R, Balzano $R$, Braga $M$. Hyperthyroidism and concurrent thyroid cancer. Tumori 1999; 85: 247-252

22 Gabriele R, Letizia C, Borghese M, De Toma G, Celi M, Izzo L, Cavallaro $A$. Thyroid cancer in patients with hyperthyroidism. Horm Res 2003; 60: 79-83

23 Miccoli P, Minuto MN, Galleri D, D’Agostino J, Basolo F, Antonangeli L, Aghini-Lombardi F, Berti P. Incidental thyroid carcinoma in a large series of consecutive patients operated on for benign thyroid disease. ANZ J Surg 2006; 76: 123-126

24 Lin CH, Chiang FY, Wang LF. Prevalence of thyroid cancer in hyperthyroidism treated by surgery. Kaohsiung J Med Sci 2003; 19: 379-384

25 Zanella E, Rulli F, Muzi M, Sianesi M, Danese D, Sciacchitano S, Pontecorvi A. Prevalence of thyroid cancer in hyperthyroid patients treated by surgery. World J Surg 1998; 22: 473-478

26 Calò PG, Tatti A, Farris S, Malloci A, Nicolosi A. Differentiated thyroid carcinoma and hyperthyroidism: a frequent association? Chir Ital 2005; 57: 193-197

27 Fukunaga FH, Lockett LJ. Thyroid carcinoma in the Japanese in Hawaii. Arch Pathol 1971; 92: 6-13

28 Fukunaga FH, Yatani R. Geographic pathology of occult thyroid carcinomas. Cancer 1975; 36: 1095-1099

29 Habra MA, Hijazi R, Verstovsek G, Marcell M. Medullary thyroid carcinoma associated with hyperthyroidism: a case report and review of the literature. Thyroid 2004; 14: 391-396

30 Alagöl F, Tanakol R, Boztepe H, Kapran Y, Terzioglu T, Dizdaroglu F. Anaplastic thyroid cancer with transiet thyrotoxicosis: case report and literature review. Thyroid 1999; 9: 1029-1032

31 Belfiore A, Garofalo MR, Giuffrida D, Runello F, Filetti S, Fiumara A, Ippolito $O$, Vigneri $R$. Increased aggressiveness of thyroid cancer in patients with Graves' disease. J Clin Endocrinol Metab 1990; 70: 830-835

32 Pellegriti G, Belfiore A, Giuffrida D, Lupo L. Vigneri Outcome of Differentiated Thyroid Cancer in Graves' Patients. J Clin Endocrinol Metab 1998; 83: 2805-2809

33 Yeo PP, Wang KW, Sinniah R, Aw TC, Chang CH, Sethi VK, Tan BC, Lim P. Thyrotoxicosis and thyroid cancer. Aust N Z J Med 1982; 12: 598-593

34 Farbota LM, Calandra DB, Lawrence AM, Paloyan R. Thyroid carcinoma in Graves' disease. Surgery 1985; 98: 1145-1152

35 Lee J, Nam KH, Chung WY, Soh EY, Park CS. Clinicopathologic features and treatment outcomes in differentiated thyroid carcinoma patients with concurrent Graves' disease. J Korean Med Sci 2008; 23: 796-801

36 Foppiani L, Del Monte P, Marugo A, Arlandini A, Sartini G, Marugo M, Bernasconi $D$. Heterogeneous malignancy in toxic thyroid nodule, letter to the Editor. J Endocrinol Invest 2005; 28: 294-295

37 Gerenova J, Buysschaert M, de Burbure CY, Daumerie C. Prevalence of thyroid cancer in Graves's disease: a retrospective study of a cohort of 103 patients treated surgically. Eur J Intern Med 2003; 14: 321-325

38 Erbil Y, Barbaros U, Ozbey N, Kapran Y, Tükenmez M, Bozbora A, Ozarmağan S. Graves' disease, with and without nodules, and the risk of thyroid carcinoma. J Laryngl Otol 2008; 122: 291-295

39 Kraimps JL, Bouin-Pincau MH, Mathonnet M, De Calan L, Ronceray J, Visset J, Marechaud R, Barbier J. Multicentre study of thyroid nodules in patients with Graves' disease. Br J Surg 2000; 87: 1111-1113

40 Behar R, Arganini M, Wu TC, McCormick M, Straus FH, DeGroot LJ, Kaplan EL. Graves' disease and thyroid cancer. Surgery 1986; 100: $1121-1127$ 
41 Ain KB. Papillary thyroid carcinoma - etiology, assessment and therapy. Endocrinol Metab Clin North Am 1995; 24: 711-760

42 Kikuchi S, Noguchi S, Yamashita H, Uchino S, Kawamoto H. Prognosis of small thyroid cancer in patients with Graves' disease. Br J Surg 2006; 93: 434-439

43 Stocker DJ, Burch HB. Thyroid cancer yield in patients with Graves' disease. Minerva Endocrinol 2003; 28: 205-212

44 Kim WB, Han SM, Kim TY, Nam-Goong IS, Gong G, Lee HK, Hong SJ, Shong YK. Ultrasonographic screening for detection of thyroid cancer in patients with Graves' disease. Clin Endocrinol (Oxf) 2004; 60: 719-725

45 Edmonds CJ, Tellez M. Hyperthyroidism and thyroid cancer. Clin Endocrinol (Oxf) 1998; 28: 253-259

46 Yano $Y$, Shibuya H, Kitagawa W, Nagahama M, Sugino K, Ito $K$, Ito $K$. Recent outcome of Graves' disease patients with papillary thyroid cancer. Eur J Endocrinol 2007; 157: 325-329

47 Duh QY. Thyroid cancer in Graves' disease: incidental cancer versus clinical cancer. Ann Surg Oncol 2004; 11: 356-357

48 Phitayakorn $R, M c H e n r y C R$. Incidental thyroid carcinoma in patients with Graves' disease. Am J Surg 2008; 195: 292-297

49 Chao TC, Lin JD, Chen MF. Surgical treatment of thyroid cancers with concurrent Graves disease. Ann Surg Oncol 2004; 11: 407-412

50 Belfiore A, La Rosa GL, La Porta GA, Giuffrida D, Milazzo G, Lupo L, Regalbuto C, Vigneri R. Cancer risk in patients with cold thyroid nodules. Relevance of iodine intake, sex, age and multinodularity. Am J Med 1992; 93: 363-369

51 Welker MJ, Orlov D. Thyroid Nodules. Am Fam Phycisian 2003; 67: 3

52 Mazzaferri EL. Thyroid cancer in thyroid nodules: finding a needle in the haystack. Am J Med 1992; 93: 359-362

53 Belfiore A, Russo D, Vigneri R, Filetti S. Graves' disease, thyroid nodules and thyroid cancer. Clin Endocrinol 2001; 55: 711-718

54 Stocker DJ, Foster SS, Solomon BL, Shriver CD, Burch HB. Thyroid cancer yield in patients with Graves' disease selected for surgery on the basis of cold scintiscan defects. Thyroid 2002; 12: 305-311

55 Gharib H, Papini E, Paschke R, Duick DS, Valcalvi R, Hegedüs L, Vitti P; AACE/AME/ETA Task Force on Thyroid Nodules 2010. American Association of Clinical Endocrinologists, Associazione Medici Endocrinologi and European Thyroid Association medical guidelines for clinical practice for the diagnosis and management of thyroid nodules executive summary and recommendations. J Endocrinol Invest 2010; 33: 287-291; Hot Thyroidology 4: 1-88; Endocr Pract 16 (Suppl 1): 1-43

56 Centeno BA, Szyfelbein WM, Daniels GH, Vickery AL Jr. Fine needle aspiration biopsy of the thyroid gland in patients with prior Graves' disease treated with radioactive iodine. Morphologic findings and potential pitfalls. Acta Cytol 1996; 40: 1189-1197

57 Anderson SR, Mandel S, LiVolsi VA, Gupta PK, Baloch ZW. Can cytomorphology differentiate between benign nodules and tumors arising in Graves' disease? Diagn Cytopathol 2004; 31: 64-67

58 Ozaki O, Ito K, Mimura T, Sugino K, Kitamura Y, Iwabuchi H, Kawano $M$. Thyroid carcinoma after radioactive iodine therapy for Graves' disease. World J Surg 1994; 18: 518-521

59 Rees Smith B, McLachlan SM, Furmaniak J. Autoantibodies to the thyrotropin receptor. Endocr Rev 1988; 9: 106-121

60 Filetti S, Belfiore A, Amir SM, Daniels GH, Ippolito O, Vigneri R, Ingbar $\mathrm{SH}$. The role of thyroid-stimulating antibodies of Graves' disease in differentiated thyroid cancer. N Engl J Med 1988; 318: 753-759

61 Morshed SA, Latif R, Davies TF. Characterization of thyrotropin receptor antibody-induced signaling cascades. Endocrinology 2009; 150: 519-529

62 Noguchi S, Yamashita H, Murakami N, Nakayama I, Toda M, Kawamoto $\mathrm{H}$. Small carcinomas of the thyroid: a long-term follow-up of 867 patients. Arch Surg 1996; 131: 187-191

63 Pacini F, Schlumberger $M$, Dralle H, Elisei R, Smit JWA, Wiersinga W and the European Thyroid cancer Taskforce. European consensus for the management of patients with differentiated thyroid carcinoma of the follicular epithelium. Eur J Endocrinol 2006; 154: 787-803

64 Cooper DS, Doherty GM, Haugen BR, Kloos RT, Lee SL, Mandel SJ, Mazzaferri EL, Mclver B, Sherman SI, Tuttle RM. Management guidelines for patients with thyroid nodules and differentiated thyroid cancer. Thyroid 2006; 16: 109-142

65 Cooper DS, Doherty GM, Haugen BR, Kloos RT, Lee SL, Mandel SJ, Mazzaferri EL, McIver B, Pacini F, Schlumberger M, Sherman SI, Steward DL, Tuttle RM. Revised American Thyroid Association management guidelines for patients with thyroid nodules and differentiated thyroid cancer. American Thyroid Association (ATA) Guidelines Taskforce on Thyroid Nodules and Differentiated Thyroid Cancer. Thyroid 2009; 19: 1167-1214
66 Stålberg P, Svensson A, Hessman O, Akerström G, Hellman P. Surgical treatment of Graves' disease: evidence-based approach. World J Surg 2008; 32: 1269-1277

67 Ikekubo K, Hino M, Ito H, Otami M, Yamaguchi H, Saiki Y, Ui K, Habuchi $Y$, Ishihsra T, Mori T. Thyroid carcinoma in solitary hot thyroid lesions on Tc-99m sodium pertechnetat scans. Ann Nucl 1989; Med 3: 31-36

68 Uludag M, Yetkin G, Citgez B, Isgor A, Basak T. Autonomously functioning thyroid nodule treated with radioactive iodine and later diagnosed as papillary thyroid cancer. Hormones (Athens) 2008; 7: $175-179$

69 Cirillo RL Jr, Pozderac RV, Caniano DA, Falko JM. Metastatic pure papillary thyroid carcinoma presenting as a toxic hot nodule. Clin Nucl Med 1998; 23: 345-349

70 Majima T, Doi K, Komatsu Y, Itoh H, Fukao A, Shigemoto M, Takagi C, Corners J, Mizuta N, Kato R, Nakao K. Papillary thyroid carcinoma without metastases manifesting as an autonomously functioning thyroid nodule. Endocr J 2005; 52: 309-316

71 Low SC, Sinha AK, Sundram FX. Detection of thyroid malignancy in a hot nodule by fluorine-18-fluorodeoxyglucose positron emission tomography. Singapore Med J 2005; 46: 304-307

72 Ahuja S, Ernst $H$. Hyperthyroidism and thyroid carcinoma. Acta Endocrinol (Copenh) 1991; 124: 146-151

73 Mizukami Y, Michigishi T, Nonomura A, Yokoyama K, Noguchi M, Hashimoto T, Nakamura S, Ishizaki T. Autonomously functioning (hot) nodule of the thyroid gland. A clinical and histopathologic study of 17 cases. Am J Clin Pathol 1994; 101: 29-35

74 Hamburger JI. Solitary autonomously functioning thyroid lesions. Diagnosis, clinical features and pathogenetic considerations. Am J Med 1975; 58: 740-748

75 Goretzki P, Wahl RA, Branscheid D, Joseph K, Tsuchiya A, Roher HD. Indication for operation of patients with autonomously functioning thyroid tissue in endemic goiter areas. World J Surg 1985; 9: 149-155

76 Harach HR, Sanchez SS, Williams ED. Pathology of the autonomously functioning (hot) thyroid nodule. Ann Diagn Pathol 2002; 6: 10-19

77 Smith M, McHenry C, Jarosz H, Lawrence AM, Paloyan E. Carcinoma of the thyroid in patients with autonomous nodules. Am Surg 1988; 54: 488-489

78 Schröder S, Marthaler B. Autonomy and malignancy of thyroid glad tumors. A critical analysis of the literature on the existence of hyperfunctioning follicular and papillary thyroid gland carcinomas. Pathologe 1996; 17: 349-357

79 Daumerie C, Ayoubi S, Rahier J, Buysschaert M, Squifflet JP. Prevalence of thyroid cancer in hot nodules. Ann Chir 1998; 52: 444-448

80 Croom RD $3^{\text {rd }}$, Thomas CG Jr, Reddick RL, Tawil MT. Autonomously functioning thyroid nodules in childhood and adolescence. Surgery 1987; 102: 1101-1108

81 Niedziela M, Breborowicz D, Trejster E, Korman E. Hot nodules in children and adolescents in western Poland from 1996 to 2000: clinical analysis of 31 patients. J Paediatr Endocrinol Metab 2002; 15: 823-830

82 Als C, Gedeon P, Rosler H, Minder C, Netzer P, Laissue JA. Survival analysis of 19 patients with toxic thyroid carcinoma. J Clin Endocrinol Metab 2002; 87: 4122-4127

83 Niepomniszcze H, Suarez H, Pitoia F, Pignatta A, Danilowicz K, Manavela $M$, Elsner $B$, Bruno $O D$. Follicular carcinoma presenting as autonomous functioning thyroid nodule and containing an activating mutation of the TSH receptor (T6201) and a mutation of Ki-RAS (G12C) genes. Thyroid 2006; 16: 497-503

84 Spambalg D, Sharifi N, Elisei R, Gross JL, Medeiros-Neto G, Fagin JA. Structural studies of the thyrotropin receptor and GS $\alpha$ in human thyroid cancers: low prevalence of mutations predicts infrequent involvement in malignant transformation. J Clin Endocrinol Metab 1996; 81: 3898-3901

85 Russo D, Tumino S, Arturi F, Vigneri P, Grasso G, Pontecorvi A, Filetti $S$, Belfiore A. Detection of an activation mutation of the thyrotropin receptor in a case of autonomously hyperfunctioning thyroid insular carcinoma. J Clin Endocrinol Metab 1997; 82: 735-738

86 Russo D, Wong MG, Costance G, Chiefari E, Treseler PA, Arturi F, Filetti S, Clark OH. A Val 677 activating mutation of the thyrotropin receptor in a Hürthle cell thyroid carcinoma associated with thyrotoxicosis. Thyroid 1999; 9: 13-17

87 Camacho P, Gordon D, Chiefari E, Yong S, Dejong S, Pitale S, Russo D, Filetti $S$. A Phe 486 Thyrotropin receptor mutation in an autonomously functioning folliculer carcinoma that was causing hyperthyroidism. Thyroid 2000; 10: 1009-1012 
88 Mircescu H, Parma J, Huot C, Deal C, Oligny LL, Vassart G, Van Vliet $G$. Hyperfunctioning malignant thyroid nodule in an 11-year-old girl: pathologic and molecular studies. J Pediatr 2000; 137: 585-587

89 Fuhrer D, Tannapfel A, Sabri O, Lamesch P, Paschke R. Two somatic TSH receptor mutations in a patient with toxic metastasising follicular thyroid carcinoma and non-functional lung metastases. Endocr Relat Cancer 2003; 10: 591-600

90 Gozu H, Avsar M, Bircan R, Sahin S, Ahiskanali R, Gulluoglu B, Deyneli $O$, Ones T, Narin Y, Akalin S, Cirakoglu B. Does a Leu 512 Arg thyrotropin receptor mutation cause an autonomously functioning papillary carcinoma? Thyroid 2004; 14: 975-980

91 Jaeschke H, Mueller S, Eszlinger M, Paschke R. Lack of in vitro constitutive activity for three previously reported TSH receptor mutations identified in patients with non autoimmune hyperthyroidism and hot thyroid carcinomas. Clin Endocrinol (Oxf) 2010; 73: 815-820

92 Cerci C, Cerci SS, Eroglu E, Dede M, Kapucuoglu N, Yildiz M, Bulbul M. Thyroid cancer in toxic and non-toxic multinodular goiter. J Postgrad Med 2007; 53: 157-160

93 Chigot JP, Ménégaux F, Keopadabsy K, Hoang C, Aurengo A, Leenhardt $L$, Turpin $G$. Thyroid cancer in patients with hyperthyroidism. Presse Med 2000; 29: 1969-1972

94 Lian X, Bai Y, Tang W, Dai W, Guo Z. A clinical study on coincidence with hyperthyroidism and thyroid carcinoma. Zhongguo Yi Xue Ke Xue Yuan Xue Bao 2000; 22: 273-275

95 Ruggieri M, Scocchera F, Genderini M, Mascaro A, Luongo B, Paolini A. Hyperthyroidism and concurrent thyroid carcinoma. Eur Rev Med Pharmacol Sci 1999; 3: 265-268

96 Omür O, Yazc B, Akgün A, Ozcan Z, Akyldz M, Argon M, Ozklc H. Concomitant hyperthyroidism in patients with thyroid carcinoma and the effects of iodine supplementation in an iodine-deficient Area. Clin Nucl Med 2008; 33: 769-772
97 Kilpatrick R, Blomfield GW, Neal FE, Wilson GM. Carcinoma of the thyroid. J Med 1957; 26: 209-233

98 Hancock BW, Bing RF, Dirmikis SM, Munro DS, Neal FE. Thyroid carcinoma and concurrent hyperthyroidism. Cancer 1997; 39: 298-302

99 Mazzaferri EL, Young RL, Oertel JE, Kemmerer WT, Page CP. Papillary thyroid carcinoma: The impact of therapy in 576 patients. Medicine (Baltimore) 1977; 56: 171-196

100 Hall R, Ross M, Teng CS, Smith BR. Immunological aspects of thyroid cancer. Recent Results Cancer Res 1980; 73: 56-59

101 Wahl RA, Goretzki P, Meybier H, Nitschke J, Linder M, Roher HD. Coexistence of hyperthyroidism and thyroid cancer. World J Surg 1982; 6: 385-390

102 Vini L, Hyer S, Pratt B, Harmer C. Good prognosis in thyroid cancer found incidentally at surgery for thyrotoxicosis. Postgrad Med J 1999; 75: 169-170

103 Bolko P, Lacka K, Manuszewska E, Ruchala M, Majewski P, Sowinski J. Is hyperthyroidism often present in patients with thyroid differentiated carcinoma? Pol Arch Med Weun 2002; 107: 555-559

104 Gulcelik MA, Gulcelik NE, Dinc S, Kuru B, Camlibel M, Alagol H. The incidence of hyperthyroidism in patients with thyroid cancer in an area of iodine deficiency. J Surg Oncol 2006; 94: 35-39

$105 \mathrm{Zhu}$ XG, Cheng SY. Modeling thyroid cancer in the mouse. Horm Metab Res 2009; 41: 488-499

106 Frates MC, Benson CB, Charboneau JW, Cibas ES, Clark OH, Coleman $B G$, Cronan JJ, Doubilet PM, Evans DB, Goellner JR, Hay ID, Hertzberg $B S$, Intenzo CM, Jeffrey RB, Langer JE, Larsen PR, Mandel SJ, Middleton WD, Reading CC, Sherman SI, Tessler FN. Society of Radiologists in Ultrasound. Management of thyroid nodules detected at US: Society of Radiologists in Ultrasound consensus conference statement. Radiology 2005; 237: 794-800 